\title{
Biochemical and Histological Basis of Graft Compatibility in Red Globe Grapes (Vitis Vinifera L) Grafted on Different Rootstocks
}

ISSN: 2637-7659

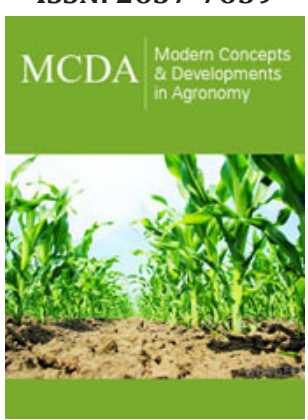

*Corresponding author: Satisha Jogaiah, Principal Scientist, Division of Fruit Crops, ICAR-Indian Institute of Horticultural Research, Hesaraghatta Lake Post, Bengaluru-560 089, India

\section{Submission: 眥 April 20, 2021}

Published: 監August 17, 2021

Volume 9 - Issue 2

How to cite this article: Satisha Jogaiah, Harikanth Porika, Kaushal Upreti. Biochemical and Histological Basis of Graft Compatibility in Red Globe Grapes (Vitis Vinifera L) Grafted on Different Rootstocks. Mod Concep Dev Agrono. 9(2). MCDA. 000709. 2021. DOI: 10.31031/MCDA.2021.09.000709

Copyright@ Satisha Jogaiah. This article is distributed under the terms of the Creative Commons Attribution 4.0 International License, which permits unrestricted use and redistribution provided that the original author and source are credited.

\section{Satisha Jogaiah ${ }^{1 *}$, Harikanth Porika ${ }^{2}$ and Kaushal Upreti ${ }^{3}$}

${ }^{1}$ Principal Scientist, Division of Fruit Crops, ICAR-Indian Institute of Horticultural Research, Hesaraghatta Lake Post, Bengaluru-560 089, India

${ }^{2}$ Assistant Professor, Fruit Research Station, Sangareddy, Telangana-502001, India

${ }^{3}$ Principal Scientist, Division of Basic Sciences, ICAR-Indian Institute of Horticultural Research, Hesaraghatta Lake Post, Bengaluru-560 089, India

\begin{abstract}
Cultivation of Red Globe grapes is gaining popularity in mild tropical climate of India owing to its bold berries and attractive red colour and better shelf life this fetching better price in market. Dogridge is the preferred rootstock in India because of its wide adoptability in different soil and climatic conditions beside its tolerance to drought and salinity. Though most of the commercial grape varieties are grafted on Dogridge rootstock, the success of grafting Red Globe onto Dogridge is very less or it needs repeated grafting for vineyard establishment. Among different rootstocks, Red Globe grafted on 110R and 66/4 (hybrid rootstock of St. George×1103P) recorded maximum graft success while it was only $41.18 \%$ on Dogridge rootstock. Higher graft success on these rootstocks might be due to biochemical status of mother plants at the time of grafting where $110 \mathrm{R}$ and 66/4 recorded highest carbohydrates, proteins, total phenols and dry matter content which was least on SO4 and Freedom rootstocks. The correlation between enzymes like polyphenol oxidase and peroxidase also plays major role in improving graft success which is evident in the present study.
\end{abstract}

Keywords: Dogridge; Graft success; Red globe; Rootstocks

\section{Introduction}

Thompson Seedless and its clonal selection are the commercially grown major grape varieties in Indian subcontinent on large scale. However, in recent decades, growers are showing much affinity towards cultivating other coloured varieties owing to their demand in international market and better price realization in both domestic and international market. Some of these coloured varieties are found to perform better in mild tropical climate of southern India (Bengaluru and surrounding areas) than in major grape growing regions of India which mostly comprises of Maharashtra and northern Karnataka which has arid tropical climate. Some of these coloured grape varieties are Flame Seedless, Sharad Seedless, Red Globe, Crimson Seedless, Fantasy Seedless etc. Owing to the problems associated with abiotic stresses like soil salinity and water scarcity, grape varieties are grafted on different rootstocks. In India the only rootstock which occupies more than $90 \%$ of the area under grape cultivation is Dogridge (Vitis champinii L). Its widely adopted by most of the grape growers owing to its advantages like salinity tolerance, drought tolerance, improving the yield and quality and well suited for less fertile soils too [1,2]. Graft success or compatibility depends on biochemical status of the rootstocks and scions at the time of grafting, water movement from root to shoot, weather parameters etc. Most of the incompatibility studies have compared the morphological and physio biochemical status of compatible and incompatible graft unions $[3,4]$. After grafting, the formation of union begins with healing of wound in the graft zone 
where cambial cells of stock and scion begin proliferating into parenchymatous cells leading to development of callus. The callus acts as a bridge between stock and scion until it differentiates the new cambium into xylem and phloem tissues thus enabling vascular connection between two parts [5]. Higher accumulation of antioxidant gene transcripts was detected by Irisarri et al. [6] in compatible grafts early during graft formation in pear/quince and thus opined that antioxidant enzymes might be associated with better protection of tissues damaged during grafting process. Polyphenol oxidase (PPO) plays a major role in cell division and differentiation and primordial development [7]. This enzyme is involved in oxidation of phenols and thus contributes for energy during cell division and differentiation. During grafting healing practice, the enzymes PPO and peroxidase play major role in oxidation of phenols thus contributing for wound healing process as reported by Zheng et al. [8] in Carya catharynsis. Considering the role of various physiological, biochemical and morphological parameters which are associated with graft union formation; this experiment was conducted to see the compatibility of Red Globe grapes grafted on different rootstocks.

\section{Material and Methods}

In this experiment, five rootstocks namely Dogridge, 110R, S04, Freedom and 66/4, a hybrid rootstock (St. George×1103P) were used to graft Red Globe grapes. The rooted cuttings of the rootstocks were planted in 14" plastic pots and maintained with regular irrigation, nutrition and plant protection measures till the plants attained graft able size (6 months).

On the day of grafting, scions were prepared from healthy mother vines by collecting the shoots having thickness similar to that of rootstocks. Each scion stick had 3-4 nodes and the basal end of the scions was made into wedge shape by removing the bark without damaging cambium. The basal wedge-shaped scions were inserted into the slit opened on the rootstocks and tightly secured with 200-gauge polythene strips. After grafting the plants were maintained by following regular fertilization, irrigation and plant protection measures.

Estimation of biochemical constituents in scions and rootstocks before grafting were analyzed using standard procedures for total proteins [9]; total phenols [10]; carbohydrates [11], nitrogen,
CN ratio (using carbohydrate-nitrogen ratio analyzer, Model: VarioMicroCube, Elementar, Germany) and dry matter content.

The graft success rate was recorded on 90 and 120 days after grafting. Total shoot length, average internodal length, stock-scion ratio was measured on 90 and120 days after grafting. Total leaf area per vine was measured on 120 days after grafting using leaf area meter (Biovis, Expert Vision India Ltd, Mumbai). The chlorophyll content [12], activity of enzymes viz., peroxidise (POD) [13] and polyphenol oxidase (PPO) [14] were estimated on 60th and 120th days after grafting.

Histological observations on graft union were taken on $120^{\text {th }}$ days after grafting by destructive samples using electron microscope as per the procedure developed by Ensikat et al. [15] for electron scanning microscope examination (Qunata 200, FEI, USA). The tissues of graft union were prepared by sectioning with sharp $7 \mathrm{~mm}$ razor blade of $3-10 \mathrm{~mm}$ size. The cut face of one selected piece was sealed with glue (conductive carbon glue) and mounted on scanning electron microscope (SEM) stubs with conductive adhesive tape. The SEM sample holder was cooled with ice close to $0{ }^{\circ} \mathrm{C}$ prior to insertion into SEM in order to slow down the desiccation. Further the images of various graft success were captured for studying the callusing and alignment of xylem and phloem.

\section{Result}

\section{Growth parameters}

Significant variation was observed for graft success on 90 and 120 days after grafting (Table 1), where in the rootstock $110 \mathrm{R}$ recorded higher graft success with $75.58 \%$ on 120 days after grafting. The success percent was $41.18 \%$ on Dogridge rootstock. The least graft success was recorded SO4 with 18.18\%. Maximum shoot length of $97.40 \mathrm{~cm}$ was recorded in Red Globe grafted on $110 \mathrm{R}$ rootstock followed by those grafted on 66/4. The least shoot length of $16.13 \mathrm{~cm}$ was recorded on Dogridge rootstock on $120^{\text {th }}$ DAG. Accordingly maximum leaf area $\left(4196.48 \mathrm{~cm}^{2}\right)$ was also highest on $110 \mathrm{R}$ rootstock followed by those on $66 / 4$ rootstock. The least area of $1352.76 \mathrm{~cm} 2$ was recorded on Dogridge rootstock. Significant difference was recorded for stock scion girth ratio wherein, Red Globe grafted on $110 \mathrm{R}$ recorded ratio nearer to 1.00 while it was least (0.87) on Dogridge rootstock. The stock scion ratio was in the range of 0.95 to 0.97 in other stock scion combinations.

Table 1: Effect rootstocks on graft success and other growth parameters in grape var. Red Globe.

\begin{tabular}{|c|c|c|c|c|c|c|c|c|}
\hline \multirow{2}{*}{ Rootstocks } & \multicolumn{2}{|c|}{ Graft Success (\%) } & \multicolumn{2}{|c|}{ Total Shoot Length (cm) } & \multicolumn{2}{|c|}{ Leaf Area $\left(\mathrm{cm}^{2}\right)$} & \multicolumn{2}{|c|}{ St/scion Ratio } \\
\hline & 60DAG & 120DAG & 60DAG & 120DAG & 60DAG & 120DAG & 60DAG & 120DAG \\
\hline Dogridge & 44.44 & 41.18 & 22.9 & 16.13 & 514.48 & 1352.76 & 0.87 & 0.87 \\
\hline Freedom & 41.67 & 29.17 & 23.75 & 37.33 & 920.03 & 1519.51 & 0.9 & 1.13 \\
\hline $110 \mathrm{R}$ & 57.14 & 75.58 & 64.1 & 97.4 & 2035.14 & 4196.48 & 0.99 & 1.02 \\
\hline SO4 & 29.17 & 18.18 & 31.78 & 44.28 & 1260.97 & 1565.28 & 0.9 & 0.93 \\
\hline $66 / 4$ & 54.81 & 51.61 & 36.5 & 69.82 & 1669.43 & 2521.18 & 0.97 & 1.02 \\
\hline $\mathrm{SE}(\mathrm{m}) \pm$ & 1.212 & 1.138 & 2.722 & 2.547 & 91.55 & 85.52 & 0.035 & 0.042 \\
\hline $\mathrm{CD}(\mathrm{p} \leq 0.05)$ & 3.688 & 3.461 & 8.28 & 7.749 & 278.48 & 260.14 & 0.106 & 0.127 \\
\hline
\end{tabular}




\section{Biochemical constitutes of rootstocks before grafting}

Significant difference was recorded for total protein and phenols with maximum of $0.816 \mathrm{mg} / \mathrm{g}$ and $9.86 \mathrm{mg} / \mathrm{g}$ respectively observed in $110 \mathrm{R}$ rootstock while least protein $(0.365 \mathrm{~g} / \mathrm{mg})$ and phenols $(6.93 \mathrm{mg} / \mathrm{g})$ was recorded in $\mathrm{SO} 4$ and Freedom rootstocks respectively. Maximum C/N ratio was observed in Freedom (49.69) and least of 44.61 were recorded in Dogridge rootstock. The $\mathrm{C} / \mathrm{N}$ ratio in other rootstocks was moderate. Similarly highest dry matter content was recorded in $110 \mathrm{R}$ rootstock $(71.02 \%)$ and least was in Dogridge and SO4 rootstocks with $58.05 \%$ and $57.59 \%$ respectively (Table 2).

Table 2: Biochemical status of mother rootstocks before grafting with grape variety Red Globe.

\begin{tabular}{|c|c|c|c|c|c|}
\hline Rootstocks & Total Proteins (mg/g Fresh wt) & Total Phenols (GAE mg/g) & $\begin{array}{l}\text { Total Carbohydrates } \\
\text { Content (mg/g FW) }\end{array}$ & CN Ratio & Dry Matter Content (\%) \\
\hline Dogridge & 0.423 & 6.7 & 116.28 & 45.03 & 58.05 \\
\hline Freedom & 0.365 & 6.93 & 108.94 & 49.69 & 66.95 \\
\hline $110 \mathrm{R}$ & 0.816 & 9.86 & 158.81 & 46.61 & 71.02 \\
\hline SO4 & 0.38 & 7.5 & 127.17 & 44.96 & 57.59 \\
\hline $66 / 4$ & 0.597 & 8.36 & 145.28 & 45.06 & 70.01 \\
\hline $\mathrm{SE}(\mathrm{m}) \pm$ & 0.034 & 0.099 & 4.157 & 1.018 & 2.399 \\
\hline $\mathrm{CD}(\mathrm{p} \leq 0.05)$ & 0.1 & 0.293 & 12.3 & 3.015 & 7.102 \\
\hline
\end{tabular}

\section{Enzyme activity}

Maximum POD activity of $0.0095 \mathrm{U} / \mathrm{mg}$ protein and $0.0076 \mathrm{U} /$ $\mathrm{mg}$ protein was recorded on $110 \mathrm{R}$ and $66 / 4$ rootstocks while it was least on Dogridge (0.0026U/g protein). Similar trend was also recorded for PPO activity with highest being recorded on 110R and $66 / 4$ rootstock and least was on Freedom (Table 3).

Table 3: Effect of various rootstocks on chlorophyll and enzyme activity in grape variety Red Globe.

\begin{tabular}{|c|c|c|c|c|c|c|}
\hline \multirow{2}{*}{ Rootstocks } & \multicolumn{2}{|c|}{ Chlorophyll (mg/g) } & \multicolumn{2}{c|}{ POD Activity (U/mg Protein) } & \multicolumn{2}{c|}{ PPO Activity (U/mg Protein) } \\
\cline { 2 - 7 } & 60DAG & 120DAG & 60DAG & 120DAG & 60DAG & 120DAG \\
\hline Dogridge & 2.025 & 2.388 & 0.0068 & 0.0026 & 0.137 & 0.103 \\
\hline Freedom & 1.573 & 2.727 & 0.0054 & 0.0019 & 0.114 & 0.085 \\
\hline $110 \mathrm{R}$ & 2.416 & 2.935 & 0.0135 & 0.0095 & 0.216 & 0.146 \\
\hline SO4 & 1.739 & 2.216 & 0.0088 & 0.0035 & 0.19 & 0.13 \\
\hline $66 / 4$ & 2.077 & 2.504 & 0.0108 & 0.0075 & 0.21 & 0.184 \\
\hline SE $(m) \pm$ & 0.142 & 0.111 & 0.001 & 0 & 0.009 & 0.019 \\
\hline CD $(\mathrm{p} \leq 0.05)$ & 0.432 & 0.337 & 0.002 & 0.001 & 0.028 & 0.058 \\
\hline
\end{tabular}

\section{Histological studies}

Among the different stock scion combination, the better graft success with healing and callusing was observed in Red Globe grafted on $110 \mathrm{R}$ and 66/4 rootstock on both 60 and 120 days after grafting. The clear parenchyma tissue was observed in stock scion combination of Red Globe grafted on $110 \mathrm{R}$ and 66/4 while on other rootstocks, the vascular connection was incomplete/ discontinuous which was complete on $110 \mathrm{R}$ and 66/4 rootstocks. On $110 \mathrm{R}$ rootstock, establishment of the cambial continuity was aligned properly with its rootstock counterpart compared to other rootstocks (Figure 1).

\section{Discussion}

Among the different rootstocks studied, 110R recorded maximum proteins, total phenols, total carbohydrates and dry matter content with moderate $\mathrm{C} / \mathrm{N}$ ratio which might have contributed for better graft success. Many earlier studies have shown clearly that higher concentration of these biochemical constituents in rootstocks before grafting have direct influence on graft success [16]. In their study they confirmed that, either too high or too low $\mathrm{C} / \mathrm{N}$ ratio will adversely affect the graft success. Hence, biochemical status in the rootstocks at the time of grafting may be one of the important factors for better graft success [17]. The chance of graft success and its establishment into a healthy grafted plant increases as the genetic, physiological and anatomical differences between stock and scion are very minimal. In this context, the better graft success on $110 \mathrm{R}$ and $66 / 4$ rootstocks might be attributed to higher carbohydrate reserve in the rootstock at the time of grafting, which might have broken down into sugars and acted as source of energy for sprouting buds, their subsequent growth into new shoots and also for rapid cell division and callus development in the grafted region.

The mother vine status indicates the capacity of the rootstocks to influence different biochemical constitutes in the scion required for physiological activation of the vines. The good graft success depends on carbohydrate reserves in the mother vines selected for 
rootstocks. Similarly, Rafaat et al. [18] also evidenced that higher total carbohydrate content in Flame Seedless grafted on both Salt Creek and Freedom than on own roots. Stock scion ratio plays an important role in maintaining the uniformity of graft union thickness. This indicates the ease flow of photosynthates in the plant system thus predicting the vine longevity. The stock scion ratio will show the compatibility of scion and rootstock to form smooth graft union to some extent. Among the different stock scion combinations, Red Globe on $110 \mathrm{R}$ rootstock had better stock scion ratio nearer to 1.0 followed by those grafted on 66/4. The highest graft success on $110 \mathrm{R}$ and $66 / 4$ rootstock might also be evident from the good vascular connection between stock and scion (Figure 1) which helps in better translocation of water and mineral nutrients from stock scion for better shoot growth above the graft union. The poor vascular connection as seen in some stock scion combinations like SO4 and Freedom which might have disturbed water, nutrient and assimilate flows in the plant and might have resulted in further breakdown of union part as explained by Satisha et al. [16]. This increase in shoot growth, stem girth in the most successful rootstock and scion combination might also be attributed to total leaf area available on the shoots. The higher leaf area on 110R and B2 56 rootstocks might have resulted in more accumulation of net assimilates which might have helped in increasing the stem girth and shoot length in addition to formation of secondary metabolites which are involved in process of graft healing like enzyme substrates.

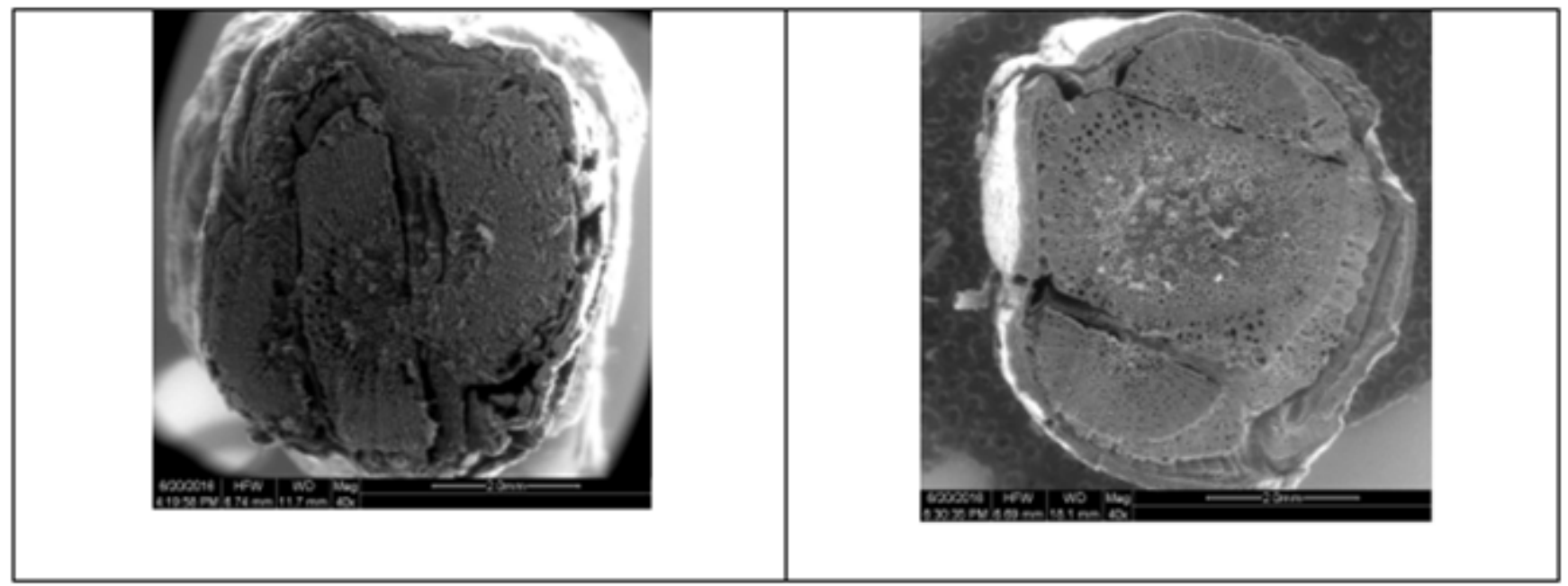

Figure 1: Anatomy of graft union of Red Globe grafted on Dogridge (left) and 110R (right) rootstocks on 120 days after grafting. Observe breakdown or discontinuity of union in left part of the figure.

Successful grafting of any plant species is formation of good callus which is prerequisite for formation of graft union both in rootstock and scion and its subsequent differentiation into vascular tissues for translocation of water and nutrients $[19,20]$. In the present experiment on effect of different rootstocks it is evident that the rootstock in stock scion combination of $110 \mathrm{R}$ and 66/4 on Red Globe showed smooth vascular connection between stock and scion which further increased the total shoot length and leaf area in the same combination compared to those on SO4 and Freedom rootstock. However, on Dogridge the graft success was moderate which might be due to less activity of antioxidant enzyme activity and also poor callusing and vascular connection. The role of endogenous substances synthesized in stock region varies with genotypes which play important role in determining graft union formation. Cookson et al. [21] reported up-regulation of genes of cell wall synthesis, secondary metabolism and signaling in combination of most compatible rootstock. Similarly, Assuncao et al. $[22,23]$ in their study also reported greater abundance of transcripts related to the hormone or pathway signaling earlier i.e., 21 days after grafting in graft combination of grape variety TN 21 grafted on $110 \mathrm{R}$ rootstock which gave better graft success. In the present study also the higher graft success and smooth vascular connection in the stock scion combination of Red Globe grafted on 110R might be due to more synthesis of auxins and cytokinin's in $110 \mathrm{R}$ rootstock.

More cytokinin synthesis in buds of Thompson Seedless grafted on $110 \mathrm{R}$ rootstock was reported earlier in our studies [2] which showed earlier bud sprout after pruning compared to those grafted on other rootstocks viz., Dogridge, 99R, St. George and 1103 P. In the same study the delayed bud sprouting in Thompson Seedless grafted on Dogridge was attributed to less cytokinin concentration produced by Dogridge rootstocks. The evidence from the stereo microscopic studies also have clearly shown the poor compatibility in Red Globe grafted on SO4, Freedom and Dogridge rootstocks which was associated with breaks/discontinuity of cambial connectivity which will lead to mechanically weak graft union and gradual starvation of root system with food material translocated from phloem. This poor translocation of water from root system to above ground part and photosynthates from leaves to below ground part pay result in vines exhibiting external symptoms like yellowing of leaves, die back etc which was also evidenced in our study on SO4 and Freedom rootstock after 120 days of grafting. 
Estimation of different biochemical constituents may also be used as the indicators for graft success. In present study, the maximum graft success was recorded in Red Globe grafted on $110 \mathrm{R}$ and B2/56 rootstock both of them recorded higher phenolic content also. Effect of phenolic compounds on reestablishment of vascular connection between stock and scion is well studied by several workers [24,25]. They have established that phenolic compounds are mostly involved in lignification which are very much important in early growth stages of connection between scion and rootstock combination [26]. Hence, in the present study also presence of higher concentration of phenols, proteins, dry matter and moderate carbohydrate nitrogen ratio in $110 \mathrm{R}$ and $\mathrm{B} 2 / 56$ rootstocks might have significantly contributed for maximum graft success. Analysis of antioxidant enzymes also serves as better indicator for graft compatibility/ incompatibility [27]. Some of the antioxidant enzymes play major role during xylem lignification of the newly differentiated vascular system after formation of graft union between stock and scion [28]. In present study also maximum activity of peroxidase was recorded on $110 \mathrm{R}$ and B2/56 rootstock which showed maximum graft success and better shoot growth and leaf area than the rootstocks viz., SO4 and Freedom which showed less graft success and minimum shoot and leaf development. This finding is in accordance with Gulen et al. [29] who reported more antioxidant enzyme activity in grafted plum plants than in control plants (Pyrus communis). Similarly, Aloni et al. [30] reported higher activity of antioxidant enzymes and lower reactive oxygen species in compatible rootstock-scion interface in melons. Similarly, higher activity of peroxidase was observed in compatible graft combinations than in incompatible ones in apricot, where in incompatibility was attributed in inefficient lignification at graft joint due to less activity of peroxidase [31].

The role of PPO in improving graft compatibility has been studied by $\mathrm{Xu}$ et al. [27]. Usually, higher phenolic compounds during grafting in mother vines with damage made during graft formation limits the proliferation and differentiation of Calli as well as formation of the new vascular tissues in incompatible grafts [32]. But PPO as protective enzymes in plants can oxidize higher phenolic compounds accumulated during grafting injury thus forming necrotic layer preventing desiccation of tissues [33]. This is evident in our study also wherein rootstock 110R exhibited high PPO activity which might have oxidized high phenolic content and thus favored more graft success compared to other rootstocks like SO4 and Freedom.

\section{Conclusion}

It is evident from the present study that graft success was maximum in Red Globe grafted on $110 \mathrm{R}$ and 66/4 rootstock while it was moderate on Dogridge and least on SO-4 and Freedom. The increased graft success on these rootstocks has been associated with increased biochemical constitutes in the rootstocks at the time of grafting viz., total phenols, total proteins, dry matter etc. Some of the antioxidant enzymes like PPO and peroxidase also plays significant role in formation of graft union which is evident in present study the rootstocks with high activity of these two rootstocks were known to record higher graft success. The success of graft union was evinced through scanning electron microscope where there was clear connection of tissues between both stock and scion in Red Globe grafted on 110R while there was disruption in the connectivity in rootstocks like SO-4 and Freedom which might be the incompatibility symptom in those rootstocks.

\section{References}

1. Somkuwar RG, Satisha J, Ramteke SD, Mundankar Y (2006) Effect of different rootstocks on graft success in flame seedless grapes. J Production Protection 2: 63-64.

2. Satisha J, Somkuwar RG, Sharma J, Upadhyay AK, Adsule PG (2010) Influence of rootstocks on growth, yield and fruit composition of Thompson Seedless grapes grown in Pune region of India. South African J Enol Vitic 31(1): 1-8.

3. Pina A, Errea P, Juel H (2012) Graft union formation and cell-to-cell communication via plasmodesmata in compatible and incompatible stem unions of Prunus spp. Sci Hortic 143: 144-150.

4. Goldschmidt EE (2014) Plant grafting: new mechanisms, evolutionary implications. Front Plant Sci 5: 727.

5. Vrisc S, Pulko B, Kocsis L (2015) Factors influencing grafting success and compatibility in grape rootstocks. Scientia Horticulturae 181: 168-173.

6. Irisarri P, Binczycki P, Errea P, Martens HJ, Pina A (2014) Oxidative stress associated with rootstock-scion interactions in pear/quince combinations during early stages of graft development. J Plant Physiol 176: 25-35.

7. Huystee RB, Cairns WL (1982) Progreno and prospects in the use of peroxidase to study cell development. Phytochem 21(8): 1843-1847.

8. Zheng BS, Liu L, Haung JQ Cheng XJ, Zhu YQ, et al. (2002) Analysis of physiological and biochemical traits of survival of Carya cathayensis grafted seedlings. J Fujian College Forestry 22: 320-324.

9. Lowry OH, Rose Brought J, Farr LA, Randael RJ (1951) Protein measurement with Folin phenol reagent. J Biol Chem 193: 265-275.

10. Singleton VL, Rossi JA (1965) A colorimetry of total phenolics with phosphomolybdic-phosphotungstic acid reagents. Am J Enol Vitic 16: 144-158.

11. Somogyi N (1952) Notes on sugar determination. J Biol Chem 200: 145154.

12. Hiscocox J, Israeistam GF (1979) DMSO method of chlorophyll determination in leaf tissues. Canadian J Bot 57: 1332-1334.

13. Chander MS (1990) Enzymatic properties association with resistance to rust and powdery mildew in peas. Indian J Hort 47(3): 341-345.

14. Selvaraj Y, Pai DK, Singh R, Roy TK (1995) Biochemistry of uneven ripernin gin Gulabi grapes. J Food and Biochem 18: 325-341.

15. Ensikat HJ, Ditsche Karu P, Barthlott W (2010) Scanning electron microscopy of plant surfaces: simple but sophisticated methods for preparation and examination. Microscopy: Science, Technology, Application and Education 248: 255.

16. Satisha J, Adsule PG (2008) Rooting behaviour of grape rootstocks in relation to IBA concentration and biochemical constituents of mother vines. Acta Hort 785: 121-126.

17. Turkmen C, Dardeniz A, Moftouglu NM, Gokbayrak Z, Kbaoglu A (2011) Nutrient content of $140 \mathrm{Ru}$ rootstocks canes in dormant season. Journal of Animal and Plant Sci 21(4): 730-733.

18. Rafaat SS, Gendy EL (2013) Evaluation of flame seedless grapevines grafted on some rootstocks. J Hort Sci and Ornamental Plants 5(1): 1-11. 
19. Hartmann HT, Kester DE, Davis FT (1990) Plant propagation-Principles and Practices. (6 $6^{\text {th }}$ edn), Prentice Hall Press, New Jersy, USA.

20. Nickell LG (1984) Plant growth regulating chemicals. CRC Press.

21. Cookson SJ, Clemente Moreno MJ, Hevin C, Mendom LZM, Delrot S, et al. (2013) Graft union formation in grapevine induces transcriptional changes related to cell wall modification, wounding, hormone signalling, and secondary metabolism. J Expt Bot 64(10): 2997-3008.

22. Assunçao M, Santos C, Brazao J, Eiras Dias JE, Fevereiro P (2016) Understanding the molecular mechanisms underlying graft success in grapevine. BMC Plant Biol 19(1): 396.

23. Assunçao M, Pinheiro J, Cruz S, Brazao J, Queiroz J, et al. (2019) Gallic acid, sinapic acid and catechin as potential chemical markers of Vitis graft success. Scientia Hor 246: 129-135.

24. Canas S, Assunçao M, Brazão J, Zanol G, Eiras Dias JE (2015) Phenolic compounds involved in grafting incompatibility of Vitis spp: development and validation of an analytical method for their quantification. Phytochem Annl 26(1): 1-7.

25. Pina A, Cookson S, Calatayud A, Trinchera A, Errea P (2017) Chapter 5-Physiological and molecular mechanisms underlying graft compatibility. In: Vegetable Grafting Principles and Practices; Colla G, Perez Alfocea F, Schwarz D (Eds.), CABI Oxfordshire: Wallingford, UK, pp: 132-154.

26. Herrero J, Carrasco AE, Zapata JM (2014) Arabidopsis thaliana peroxidases involved in lignin biosynthesis: in silico promoter analysis and hormonal regulation. Plant Physiol Biochem 80: 192-202.
27. Xu Q, Guo S, Li H, Du N, Shu S (2015) Physiological aspects of compatibility and incompatibility in grafted cucumber seedlings. J Am Soc Hort Sci 140(4): 299-307.

28. Quiroga M, Guerrero C, Botella MA, Barcelo A, Amaya I, et al. (2000) A tomato peroxidase involved in the synthesis of lignin and suberin. Plant Physiol 122(4): 1119-1127.

29. Gulen A, Arora R, Kuden A, Krebs SL, Postman J (2002) Peroxidase isozyme profiles incompatible and incompatible pears-quince graft combinations. J Amer Soc Hort Sci 127(2): 152-157.

30. Aloni B, Cohen R, Karni L, Aktas H, Edelstein M (2010) Hormonal signaling in rootstock-scion interactions. Sci Hort Amsterdam 127(2): 119-126.

31. Quesada MP, Macheix JJ (1984) Caractérisation d'une peroxydase implique, spécifiquemente dans la lignification en relation avec l'incompatibilité au greffage chez l'abricotier. Physiologie Végétale 22: 533-540.

32. Feucht WD, Treutter, Schmid P (1988) Inhibition of growth and xylogenesis and promotion of vacuolation in Prunus callus by the avanone prunin. Plant Cell Rep 7(3): 189-192.

33. Lopez Gomez E, San Juan MA, Diaz Vivancos P, Beneyto JM, Garcia Legaz MF, et al. (2007) Effect of rootstocks grafting and boron on the antioxidant systems and salinity tolerance of loquat plants (Eriobotrya japonica Lindl.). Envi Expt Bot 60(2): 151-158.

For possible submissions Click below: 